\title{
Relocating labour-intensive manufacturing firms from China to Southeast Asia: a preliminary investigation
}

\author{
Chun Yang
}

*Correspondence:
chunyang@hkbu.edu.hk
Department of Geography,
Hong Kong Baptist University,
Hong Kong Special
Administrative Region, China

*Correspondence: chunyang@hkbu.ed Hong Kong Baptist University, Administrative Region, China

\begin{abstract}
China's rise as a "world factory" since the late 1970s has been attributed to the strategic coupling of local assets in the coastal regions, viz. Pearl River Delta (PRD) and Yangtze River Delta (YRD) in the global production networks (GPNs) driven by transnational corporations (TNCs). Since 2000, these export-led regions have encountered unprecedented challenges, particularly the rising cost of labour, which have engendered spatial relocation of labour-intensive manufacturing firms from coastal China to lowercost locations such as inland China and neighbouring Southeast Asian countries. A rich body of literature has examined the internal relocation of TNCs from coastal to inland China, relatively little has been conducted on cross-border industrial relocation out of China to Southeast Asian countries. Drawing upon the global production networks (GPNs) perspective, this study attempts to examine the relocation of TNCs from China's coastal regions, e.g. the Pearl River Delta (PRD) to Southeast Asian countries, e.g. Indonesia, Vietnam and Cambodia. Particular attention is paid to the rise of Global South and its subsequent implications for the restructuring of global manufacturing in the increasingly globalizing economy.
\end{abstract}

\section{Background}

China's rise as a "world factory" since the late 1970s has been attributed to the strategic coupling of local assets, particularly low-cost labour in the coastal regions, viz. Pearl River Delta (PRD) and Yangtze River Delta (YRD) in the Global Production Networks (GPNs) driven by transnational corporations (TNCs)'s cross-border investment. Since 2000, these export-led regions have encountered unprecedented challenges, especially the rising cost of labour, land, shortage of labour, policy changes, and shrinking market demand of western advanced economies, which have engendered spatial relocation of labour-intensive manufacturing firms from China to lower-cost locations, e.g. inland China and neighbouring Southeast Asia. Compared with numerous studies on the internal industrial relocation within China, i.e. from the coastal regions, e.g. the PRD and YRD to the mid and Western provinces and cities, e.g. Wuhan, Chongqing and Chengdu (He and Wang 2012; Yang 2009, 2013), little has been conducted on the cross-border production expansion to the neighbouring Southeast Asian countries, e.g. Vietnam, Indonesia and Cambodia. In the meanwhile, these Southeast Asian countries have 
implemented proactive policies to attract the inflows of TNCs with various government initiatives in the aftermath of the 2008 global financial crisis. The ongoing industrial relocation of China-based "world factory" in the rise of "Global South" particularly and its implications for the restructuring of global and regional production networks remain understudied in the literature.

The 2000s, especially the aftermath of the 2008 global financial crisis, witnessed the shift of markets for final products from Global North to South, particularly emerging economies in Asia, e.g. China and India (Cattaneo et al. 2010). Recent studies have highlighted significant and new trends of how global production networks and global value chains are restructuring the organization (Yeung and Coe 2015). Notably, GPNs and GVCs are becoming geographically more consolidated, which reflects the rise of large emerging economies (Gereffi 2014). Known initially as BRICs (Brazil, Russia, India and China), the emerging economies now include a diverse array of "growth economies" such as Mexico, South Korea, Turkey, Indonesia, the Philippines and Vietnam, which offer seemingly inexhaustible pools of relatively low-wage workers, highly capable expor-oriented manufacturers, abundant raw material, and sizeable domestic markets (O'Neill 2011). Emerging economies have turned into major production centres worldwide, although their specific roles in GPNs and GVCs may vary according to their openness to trade and foreign investment, and other strategic consideration. Nevertheless, little has been conducted to make connections between spatial relocation of production networks of TNCs and the rise of emerging markets in the Global South, in comparison with the relative decline of the US and EU as prevalent external markets for the products in China and Southeast Asian countries. It is worthwhile for noting that the industrial relocation has been undergone in the acrimonious politics of the "South China Sea" disputes. While politics, particularly the international political factors do matter in the industrial relocation, the current study has put more emphasis on the analysis of economic geographical factors, while remain that of political factors in future studies. The combination of economic and political factors will definitely make the scenario of production landscape complicated, which warrants for more comprehensive and systematic investigation on the agenda for future research.

This paper attempts to contribute to the literature through investigating cross-border relocation of labour-intensive TNCs from China to Southeast Asia since 2000. Special emphasis is put on the reorganization of regional production networks in East Asia and Southeast Asia induced by the industrial relocation. Based on intensive field investigation and in-depth interviews in the PRD as origin of industrial relocation and selected countries such as Cambodia, Vietnam and Indonesia as sample destinations in Southeast Asia, it sheds light on Southeast Asian countries as emerging locations for the expanded industrial space beyond the coastal regions in China's "world factory".

\section{Research design and methods}

Since 2000, particularly at the onset of the 2008 global financial crisis, the global economy has entered a new era with the rise of contending centres of economic and political power, particularly in East Asia (Cattaneo et al. 2010). Over the last two decades, the concepts of global commodity chains (GCC), global value chains (GVC) and global production networks (GPN) have become popular analytical frameworks with which to 
explore the changing landscapes of economic globalization and its associated developmental outcomes (Coe et al. 2004, 2008; Gereffi et al. 2005). From the GPN perspective, firms in developing countries have attempted to engage in "strategic coupling" with GPNs to foster regional development (Yeung 2009). Recent literature, however, argues that the concept is not explanatory enough and does not sufficiently take into account decoupling and recoupling dynamics (MacKinnon 2012). In the changing geographical political economy of GPNs, increasing attention has been paid to the negative effects, or "dark sides" of strategic coupling of export-oriented regions, e.g. over reliance on the Western markets (Henderson and Nadvi 2011). Recently, the so-called "GPN 2.0" was proposed to offer novel theoretical insights into why and how the organization of global production networks varied significantly within and across different industries, sectors and economies (Coe and Yeung 2015). Moreover, the concepts of "decoupling" and "recoupling" have been recently proposed to refine the strategic coupling of regional economies in GPNs (MacKinnon 2012). As put Yeung and Coe (2015), "Processes of decoupling and recoupling can take place thereafter, incorporating new groups and/or recombining existing groups of regional and GPN actors". By examining India's pharmaceutical industry, Horner (Horner 2014) demonstrated that the dynamic process of strategic coupling, decoupling and recoupling between 1947 and 2005 enabled India to become one of the world's leading centres for pharmaceutical production. MacKinnon (2012) contends that decoupling is a more likely outcome after structural coupling in those places such as old industrial regions in Western Europe and North America. Similar to the thesis of decoupling, "disarticulation" has emerged in the severe consequences of regional lock-in in the apparel industry in La Laguna, Mexico (Bair and Werner 2011).

Over the past decades, countries in East Asia have been successful in joining global and regional production networks, which has led to a so-called "triangular trade" pattern (Baldwin and Lopez-Gonzalez 2015): China as an export base to assemble components and parts imported from Asian NIEs and Japan into final goods for external markets in the US and EU. Moreover, an increasing share of trade in consumption goods has become reoriented over the past 5 years (2009-2014): more final goods are now being exported to countries within East Asia (Helble 2014). The rise of Asia, particularly China, has turned into not only a low cost global supply base for advanced economies, but, more importantly, has created new demand for goods and services previously destined for consumption only in advanced economies (Kaplinsky et al. 2011). The thesis of "decoupling", or the trade of East Asia's delinking from the American and European markets and "recoupling" with emerging markets within East Asia, has aroused wide attention since the early 2000s, particularly at the onset of the global financial crisis (Pula and Peltonen 2009). The notion of "decoupling" postulates that East Asia has become a self-contained economic entity for maintaining its own growth dynamism independent of the traditionally developed markets. During the period of 1995 and 2008, the share of high-income countries in total value-added generated by manufacturing industry declined from 74 to $56 \%$, and the share of Japan and the East Asian NIEs declined from 21 to $11 \%$. During the same period, emerging economies have increased their shares of valued added in manufacturing by $18 \%$. China alone is responsible for half of this increase, with its global share rising rapidly from 4 to $13 \%$ (Timmer et al. 2014). 
The export-oriented development in East Asia's newly industrialized economies (NIEs) was initially designated as a model for China in the late 1970s, and, particularly, the PRD and YRD at a later stage. The export-oriented production regions in China have benefited from the "strategic coupling" process of regional assets (cheap labour and land) and the strategic needs of GPNs (cost-down and time-to-market) through conducive institutions (processing trade regime) (Yang 2012). However, since 2000, the export-led regions have encountered unprecedented challenges at global, national and local levels, including the surge of labour costs, stringent labour and environment regulation, appreciation of Renminbi and decreasing orders from the sluggish demand of the core Western markets (Yang 2007). Prior to the 2008 global financial crisis, Guangdong provincial government initiated a so-called 'Empty the Cage for New Birds' strategy, through which labour-intensive and low-end TNCs as 'old birds' are forced to move out of the PRD to the less developed areas, while the PRD would be replaced by high-tech value-added industries as 'new birds' (Yang 2012, 2014). The outbreak of the 2008 global financial crisis has accelerated the spatial "fix" of the "world factory" (Zhang 2014) characterized by relocation of export-oriented production to lower-cost locations, including intraregional relocation in the YRD (Wei 2015), inter-regional relocation (Yang 2009) and expansion to inland China (He et al. 2011), as well as neighbouring Southeast Asia (Zhu and Pickles 2014). Taking the apparel industry as a case, Zhu and Pickles (2014) describe the restructuring process as "go up", "go west" and "go out". Existing literature on industrial relocation has primarily focused on internal industrial relocation within China, little has been conducted on cross-border production expansion to Southeast Asia, the effects of which on the restructuring of global and regional production network lack comprehensive and updated investigation.

The notion of the "Factory Asia" first emerged as a manufacturing power in the 1960s, when Japan began exporting electronics and consumer goods, followed by the Asian Newly Industrializing Economies, namely Taiwan, South Korea, Singapore and Hong Kong. By the 1980s Japanese firms were building plants across Southeast Asia. China became the most attractive location of the Factory Asia since its implementation of opening and reform in late 1970s. Asia's contribution to the global manufacturing output increased from $26.5 \%$ in 1990 to $46.5 \%$ in 2013. Among which, China accounts for half of the Asia's manufacturing output. In the meanwhile, Asia's share of the global trade in intermediate inputs-the goods that are eventually assembled into final products for exports to the advanced Western markets-rose from $14 \%$ in 2000 to $50 \%$ in 2012 (The Economist 2015).

However, since 2000, the low-end manufacturing in China's "world factory" has been weakened by the afore-mentioned rising labour costs in China, state initiatives of industrial upgrading and the unabated appreciation of the Renminbi. This will be especially true for the many cost-sensitive foreign companies currently operating in China. The illustration below shows how the unit labour cost in China continued to increase rapidly from 2008 onward, despite the decline in external demand caused by the global economic downturn. Unit labour cost in China has undergone a much steeper climb than that in Southeast Asia's other exporter economies (Fig. 1). The incipient rise of Southeast Asia offers a big labour pool with low wages and mostly market-friendly policy environments. The average factory worker in China earns $\$ 27.50$ per day, compared with $\$ 8.60$ 


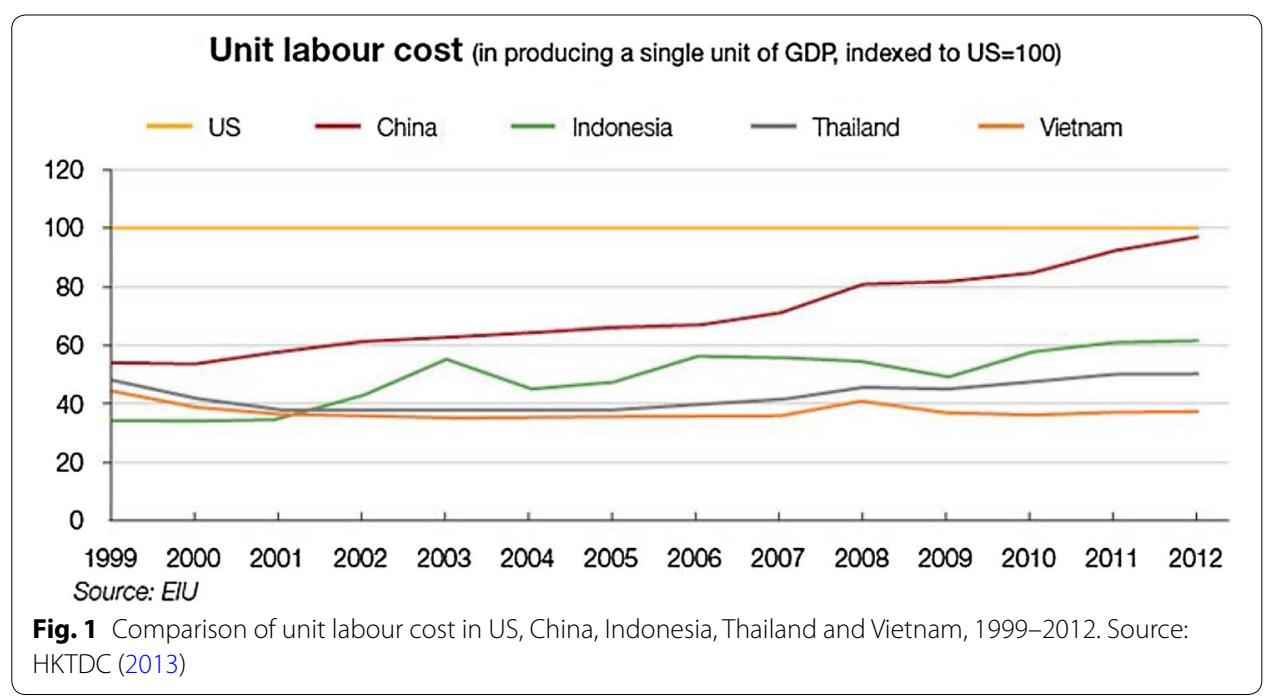

in Indonesia and $\$ 6.70$ in Vietnam. Demography is another advantage: China may be ageing rapidly, but South-East Asia's workforce is largely below the global median age of 29.7 (The Economist 2015). While the minimum wage levels in China may appear to be in line with other ASEAN countries, such as Thailand (US\$230) and Indonesia (US\$228), China's average wage is a lot higher, often double the minimum wage. As an indication, the average wage in Southern China is already above US $\$ 400$ per month, almost twice that in Thailand or Indonesia and triple the level in Vietnam (Hong Kong Trade Development Council 2013). Apart from the increased wages, China has also seen a number of its other operational costs rise, making basic manufacturing less attractive financially. China has a labour force of more than 800 million, the largest in the world. It is more than double the ASEAN's combined workforce of just over 300 million. The combined ASEAN workforce, though, is sufficiently large (and sufficiently skilled) to tempt foreign companies should they consider relocating some of their basic manufacturing away from China. In recent years, China's pace of workforce expansion has slowed, increasing at no more than one per cent a year since the beginning of the global financial crisis. Over the same period, most ASEAN countries have seen their labour forces expand at a faster rate, on average double that of China (Table 1).

Since 2000, especially in the aftermath of the 2008 global financial crisis, there has witnessed the spatial relocation of labour-intensive manufacturing firms from the coastal China to Southeast Asia. For instance, Myanmar's clothing exports jumped from $\$ 700 \mathrm{~m}$ to $\$ 1.7$ billion between 2011 and 2014. H\&M, a European retailer, recently shifted sweater production from China to the Myanmar Century Liaoyuan Knitted Wear factory, a Chinese-run facility in outer Yangon (HKTDC 2013). Taiwan-based contract manufacturer Foxconn signed a letter of intention 2011 to invest up to \$1 billion in Jakarta Province in Indonesia as it seeks to diversify production away from China. The letter states that the city has committed to provide a 200-hectare plot of land in Marunda, Central Jakarta, for the upcoming factory. The agreement was signed jointly by Foxconn chairman Terry Gou and Jakarta governor Joko Widodo. Foxconn operations in Indonesia would focus on the domestic market of around 240 million people, 
Table 1 Comparison of labour force in selected Asian economies (millions). Source: compiled according to the World Bank database

\begin{tabular}{lrrrrr}
\hline ASEAN & $\mathbf{2 0 0 8}$ & $\mathbf{2 0 0 9}$ & $\mathbf{2 0 1 0}$ & $\mathbf{2 0 1 1}$ & CAGR (\%) \\
\hline Laos & 3.0 & 3.1 & 3.2 & 3.2 & 2.7 \\
Cambodia & 7.6 & 7.8 & 8.0 & 8.1 & 2.3 \\
Malaysia & 11.5 & 11.7 & 12.0 & 12.2 & 1.9 \\
Myanmar & 27.2 & 27.6 & 28.0 & 28.4 & 1.5 \\
Philippines & 36.7 & 37.8 & 38.7 & 39.7 & 2.6 \\
Thailand & 39.2 & 38.6 & 39.4 & 39.8 & 0.5 \\
Vietnam & 49.3 & 50.2 & 51.1 & 52.0 & 1.8 \\
Indonesia & 114.3 & 116.4 & 118.0 & 119.8 & 1.6 \\
Total & 288.9 & 293.2 & 298.3 & 303.2 & 1.6 \\
China & 786.8 & 793.8 & 799.5 & 806.0 & 0.8 \\
\hline
\end{tabular}

CAGR compound annual growth rate

he said, but the company could also export to the rest of the South-east Asian region. In 2013 Japanese investment doubled in South-East Asia and shrank by $40 \%$ in China (The Economist 2015). Moreover, the state-designated economic rebalancing of China reflected in the National 12th Five-Year Plan (2011-2016), coupled with the government's increased emphasis on industrial upgrades for higher-value production, has diminished China's appeal as a location for low-cost, labour-intensive manufacturing. The scenario of "China makes all" has gradually come under challenges. Furthermore, rising domestic consumption in China has helped TNCs relocated in neighbouring regions. As the purchasing power of Chinese buyers grows, the average distance travelled by consumer-goods exports is changing, depending on whether they are shipped from Asia, Europe or North America. From 2008 to 2012, the average journey length for Asian exports fell by $4.5 \%$, while those from Europe and North America rose by 25.9 and $13.7 \%$, respectively. That makes transportation costs cheaper for Asian factories (The Economist 2015). While with well recognition of the influential political factors, i.e. the "South China Sea" disputes, the comprehensive analysis of political issues will remain in another study in future. Instead, this paper puts more emphasis on economic geographical aspects of cross-border relocation of manufacturing production from China to Southeast Asia.

At the above conceptual and empirical backdrops, this study develops a multi-scalar framework (Fig. 2) to examine the ongoing cross-border relocation of TNCs, particularly labour-intensive firms in garment and electronics industry from the PRD in coastal China to selected Southeast Asian countries, e.g. Indonesia, Vietnam and Cambodia. Since 2005, the China-based TNCs engaging in labour-intensive, environment-polluting, low value-added industries have been designated by the Chinese government as major targets for industrial restructuring (Yang 2012). Garment and electronics industries, two typical export-oriented sectors in China, are selected to examine the industrial relocation and expansion of cross-border production networks to Southeast Asia. As the largest manufacturer of electronics products in the world, China accounted for $41.4 \%$ of the world total in 2013, much higher than the EU who is number two at $23 \%$. In terms of the garment industry, China's exports accounted for $36 \%$ of the world total in 2013, which is higher than the EU at 25 \% (UN Comtrade dataset). Moreover, China's share 


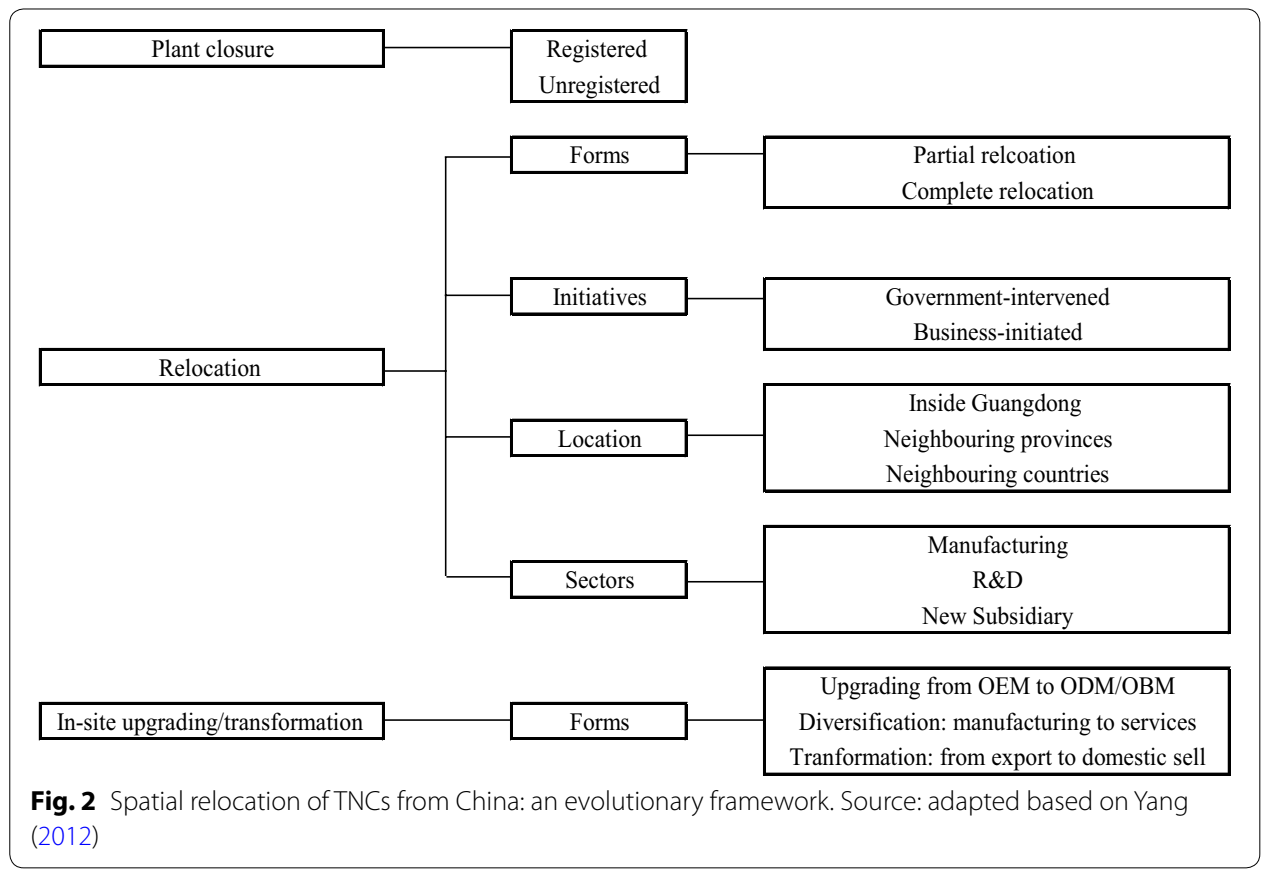

of exports of electronic final products manufactured in Southeast Asia increased from $1.4 \%$ in 2000 to $13 \%$ in 2012, while that of the US dropped from 32.9 to $17 \%$ during the same period. Indonesia, Cambodia and Vietnam are chosen as cases because they have experienced rapid transformation as emerging players in regional production networks in Southeast Asia and become major destinations of industrial relocation of China's manufacturing. For instance, Cambodia has emerged into the region's textile manufacturing centre, with more than $85 \%$ of its exports made up of garments. In 2013, Cambodia and Vietnam accounted for 21 and $29 \%$, respectively, of China's imports of apparel from ASEAN. Vietnam alone represented for $43 \%$ of China's imports of textile from ASEAN. Case studies of typical TNCs which have engaged in industrial relocation from coastal China to Southeast Asia will be conducted to better understand the inter-firm and intra-firm linkages in the expansion and reorganization of production and trade networks. It is worthwhile for noting that in the open-ended interviews, questions related to the social, linguistic and cultural differences between the selected ASEAN countries/ cities have been put forward to the interviewees to elaborate how they have influenced on the effectiveness of the process and patterns of industrial relocation and expansion of the "world factory" from China to Southeast Asia.

\section{Results and discussions}

Over the past decades, China has come to be regarded as the undisputed global workshop for making a plethora of finished goods for global consumption, especially in the G2 markets of the US and the EU. This has been helped, in no small measure, by the rapid economic development of China following its implementation of its big bang economic reforms in line with the country's accession to World Trade Organization (WTO) membership back in late 2001. As China phased in all of its liberalisation commitments to further open up its market to the world in the late 2000s, it concomitantly inspired 
increased confidence among TNCs as to increasing their China-bound investment as well as to relocating a portion of their production to the country. This resulted in a veritable transformation of China's economy. This has also catalysed the development in Asia of an integrated production base for the global supply chain. This has seen non-China Asia increasingly sending its intermediate goods to China for final assembly before shipping to overseas markets. This practice, in terms of export share, roughly doubled to about 16 per cent between 2001 and 2009. China's exports of consumer goods accounted for $30 \%$ of overall export growth, compared to around five to $10 \%$ in other Asian economies over the decade to 2009 (Fig. 3). On the other hand, those exporter countries were heavily engaged in the trading of intermediate goods, particularly those parts and components used in the production of electronic products, which underlines Asia's growing intra-regional trade.

As in many other emerging markets, a number of ASEAN countries, despite boasting a low-cost production environment and attractively low labour wages, faces a number of shortcomings. Aside from general wage levels, there is a number of other relocation considerations, including land costs, the availability of skilled labour, utility costs, infrastructure concerns, the complexity and transparency of government regulations and uncertainties as to tax regimes. A prime example of these additional concerns would be Myanmar. As a relatively undeveloped and recently emerging economy, it has the undoubted appeal of an average wage level less than half of that in Thailand or Indonesia. On the down side, its public electricity supply is limited just to $5 \mathrm{~h}$ in the dry season. The ASEAN-5 countries (Indonesia, Malaysia, Thailand, the Philippines and Vietnam) have all initiated a number of reforms aimed at optimising FDI inflows. These have centred on those trade and investment measures aimed at making it easier for foreign companies to start businesses, trade and enforce contracts. It is believed that these improvements will be seen as a clear response to longstanding calls for greater transparency in the

\section{Ease of doing business ranking: selected economies in Asia}

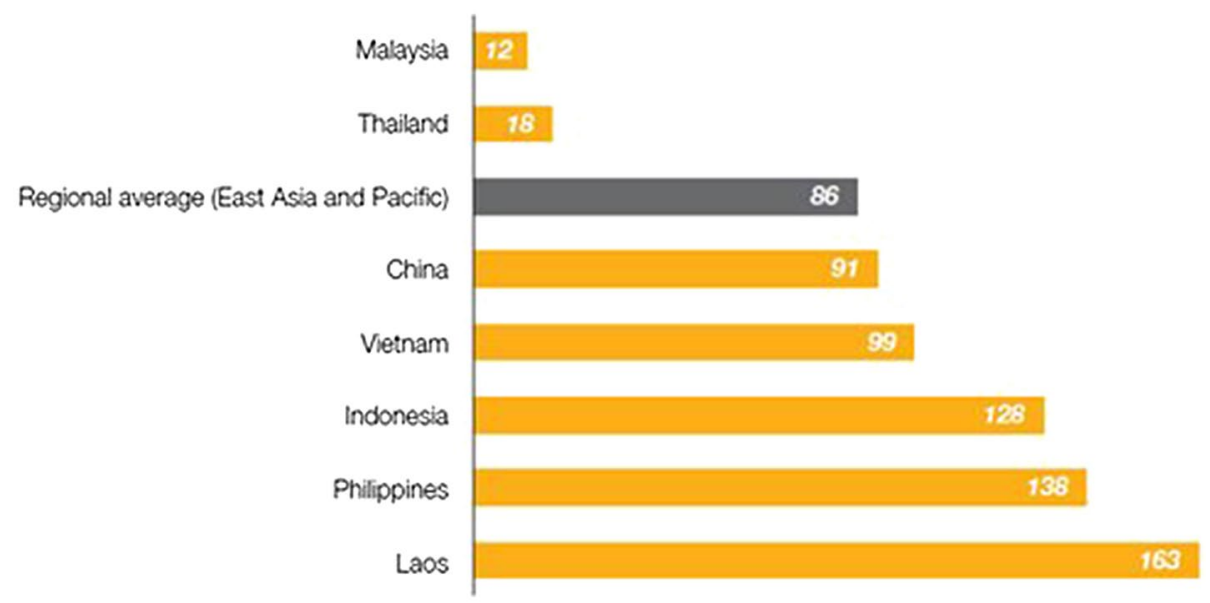

Source: Worid Bank

Fig. 3 Ranking for ease of doing business in Asia (2013). Source: HKTDC (2013) 
administration of business regulations across all of these five emerging markets. Obviously, labour cost is not a single factor and actor in determining cross-border relocation of labour-intensive manufacturing. Furthermore, market opportunities and paradigm shift of markets are also important factors in the process.

Nevertheless, the factors of business environment are more complicated than labour cost and market dynamics, salient social, political and cultural factors do matter in production relocation to the Southeast Asian countries. Notably, the World Bank currently ranks ease of doing business in 185 economies. These ratings are based on 10 individual criteria, including starting a business, dealing with construction permits, securing credit, protecting investors, access to electricity, registering property, paying taxes, trading across borders, enforcing contracts and resolving insolvency issues. If these figures were abstracted out for Asia, and China was adopted as the benchmark when considering relocation to an ASEAN-5 economy, it would appear that Vietnam is now closely behind China, with both Malaysia and Thailand also moving seemingly well out in front (Fig. 3). Looking more closely at the 2013 criteria-specific rankings, China falls behind the Philippines when it comes to securing an electricity supply, taking three times as long (i.e. 145 days versus 50 days). Although China was the world's leading exporter in 2012, it is seen to be cumbersome to trade across its borders than it is in either Indonesia or the Philippines. The problems largely stem from Chinese regulations requiring more export documents than competing nations, thus considerably lengthening the lead time for exporters working in the country.

Given ASEAN's economic diversity and its growing capacity, across the board, for handling sophisticated production of an expanding scale, it seems likely that no one ASEAN country will be the solitary beneficiary of any mass industrial relocation from China. Overall, much will depend on the exact requirements of the production facilities being relocated, as well as the perceived ease of doing business in any given ASEAN country. Despite this, Vietnam looks set to have considerable appeal, given its comparatively low wage costs and its reliable labour supply. With all the focus on facilities being relocated from China, it should be remembered that there are already signs of existing ASEANbased industrial operations considering a move from one of the region's countries to another. In particular, there have been reports indicating that a number of Thai-based garment companies are considering relocating their plants to Myanmar. These developments have been fuelled by Thailand's adoption of a daily minimum wage of about US\$10 as of January 2013.

Aside from manufacturing low cost items, such as in the flourishing garment industries of Cambodia and Vietnam, ASEAN has also become progressively more capable of handling more sophisticated manufacturing on an increasingly large scale. This is largely down to the growing availability of talented workers and the continual influx of FDI earmarked for higher-end manufacturing projects. This has seen Thailand emerge as an automotive manufacturing hub, with Indonesia also succeeding in attracting investment from abroad in the motoring sector. In 2012, electronic products overtook garments as Vietnam's leading export sector. This was largely due to increased output and exports for MNCs from the US and East Asia. Beneficiaries of this have included Samsung's factory in the Bac Ninh Province, adjacent to Hanoi. This now produces more than 100 million smartphones and tablet units annually, amounting to an export value of US\$12.5 
billion in 2012. As part of a plan to expand its business and production capabilities in Vietnam, March 2013 saw Samsung begin the construction of its second industrial complex in the country. The new facility represents an overall investment of US $\$ 2$ billion by the company and is based in Thai Nguyen Province, some $2 \mathrm{~h}$ ' drive time from Hanoi. While Thailand remains a key ASEAN investment target for Japan, despite the disruptions caused by flooding, Japanese companies have also stepped up investment in other ASEAN countries, notably Indonesia and Vietnam. This is largely in a bid to seek alternative production bases to hedge against their exposure in China. In the case of Vietnam, Japan's inward FDI in the country doubled in 2012, despite an overall double-digit decline in net FDI inflows.

Based on the field investigation and in-depth interviews with senior managers of TNCs which have engaged in cross-border relocation from China to Southeast Asia, this paper argues that the "China plus" strategy has been widely adopted by TNCs in spatial expansion and reorganization of production networks beyond China to selected Southeast Asian countries. In consequence, a China-ASEAN regional production networks has been in emerging, which will be fostered in the institutional context of China-ASEAN Free Trade Agreement effective from 1 January 2010. While some US companies are reportedly reconsidering onshore production in light of growing operating costs in China, others are planning to relocate production to Southeast Asia. Despite this, concerns over a wholesale relocation from China would appear overblown, especially taking into account Chinese workers' higher productivity, the comparative sophistication of China's industrial clusters and the country's undoubted capacity to rapidly mobilise and utilise a large amount of workers to meet substantial international orders. Although, as referenced earlier, China's inward FDI surpassed the US\$100 billion mark in 2010, this inflow decelerated somewhat in 2012. Despite this slowdown, FDI will likely remain robust in the years ahead, particularly those funds targeting China's domestic market and the production of high-value exports, as opposed to those low-value products where manufacture is likely to be relocated to other regions.

It is worthwhile for noting that apart from Southeast Asian countries, Africa has turned to be alternative locations for the relocation and expansion of labour-intensive manufacturing from China in recent years (Hong and Hong 2006). The sectoral composition, ownerships and sources of origins of the firms to Southeast Asia and Africa are found quite different. Comparative studies which take into account the economic, political, social and cultural factors are thus in need. Moreover, it is essential to develop a multi-scalar and multiple locational analytical framework to better understand the comprehensive and complicated process and dynamics of cross-border production relocation and expansion from China to the other parts of the world. More in-depth issues, e.g. adaptation and localization of foreign-invested and China-based manufacturing firms in Southeast Asian countries warrant for further research.

To summarize, the spatial relocation of TNCs from coastal China to the neighbouring Southeast Asian countries and restructuring their production networks have three major targets. Firstly, to cut down the costs. As the aforementioned, workers in the selected Southeast Asian countries generally are less expensive to hire than Chinese employees. By 2010, China already had become the third-most-expensive labor market in Asia. Moreover, labor costs have continued their upward trajectory while with difficulties in 
sufficient supply. Second, to diversify risks in the cross-border production. By taking "China plus" strategy, TNCs could geographically disperse the production across several markets to ensure producers less vulnerable to supply chain disruptions, currency fluctuations and tariff risks in various markets. Thirdly, to explore access to new markets in Southeast Asia with the rise of consumers. Nevertheless, when making decision on the location for companies to diversify away from China is not a simple one, with each country presenting its own advantages and challenges as discussed earlier. The recoupling and decoupling of developing countries and regions in the GPNs have turned into a daunting challenges for TNCs in the changing global and local dynamics.

\section{Conclusion}

This paper has conducted a preliminary exploration of the ongoing cross-border relocation of TNCs from coastal China to the Southeast Asian countries since 2000. It elucidates that the spatial expansion of China's "world factory" from coastal China regions to selected Southeast Asian countries could help the strategic coupling of regional development of the Southeast Asian countries to the GPNs. With the relocated TNCs from China, Southeast Asian countries have gradually incorporated into the GPNs. The subsequent effects on the reorganization of regional production networks have emerged, in which the intra-regional cooperation and integration has been strengthened. There witnessed the emergence of China-Southeast Asian regional production networks in the restructuring of global manufacturing and production networks. Nevertheless, as predicted by The Economist (2015), on one country in the ASEAN with 630 million people or less than half of China's population, will replace China's role in "Factory Asia". But the region will benefit if better integrated. ASEAN countries have made progress in removing tariffs, especially on goods, but non-tariff barriers on consumer goods, electronics and automobile industry remain high. The same as the restrictions on services, investment, labour mobility and customs regulations. According to the McKinsey Global Institute, the import/export costs in ASEAN (clearing customs, port fees, inland transportation) are $24 \%$ higher than China, and the time for customs procedures in ASEAN takes $66 \%$ longer than in the OECD countries.

Through relocating labour-intensive manufacturing to the Southeast Asian countries, to what extent that China could hopefully upgrade its positions from the low-end in the GPNs warrant comprehensive investigation. According to the International Federation of Robotics, China purchased $20 \%$ of the robots made in 2013 and became the biggest market for robots in the world. Foxconn, the Taiwanese firm as the largest contract manufacturer for Iphones and employed over a million workers in China forecast that robots will complete $70 \%$ of its assembly-line work within 3 years. The interaction between cross-border relocation of labour-intensive manufacturing firms from coastal Chin to Southeast Asian countries and technological upgrading in China warrants comprehensive investigation. Moreover, this study sheds light on China's growing market for the expanded production and trade networks in East and Southeast Asia, which used to mainly target the Western core markets. The findings have not only fostered the theoretical development of GPNs with the articulation of emerging host markets in Global South into the conceptual framework of GPNs, but also fundamental implications for concerned business and governments for policy making. More empirical 
studies in different countries and different industries related to the cross-border relocation of TNCs from China to Southeast Asian countries could provide more comprehensive understanding and empirical evidence to the reorganization of regional and global production networks in the interconnected global economy.

\section{Acknowledgements}

Financial supports from the General Research Grant (GRF), Research Grant Council of Hong Kong Special Administrative Region government (HKBU257210), National Natural Science Foundation of China (41571119), Faculty Research Grant (FRG1/14-15/042 and FRG2/14-15/055) of Hong Kong Baptist University are gratefully acknowledged. The earlier version of the paper was presented as a keynote speech at the International Conference on the Commemorative Academic Conference for the 60th Anniversary of the 1955 Asian-African Conference in Bandung, Indonesia, 4-6 June 2015. Thanks go to the participants of the conference for their constructive comments which helped improve the paper.

\section{Competing interests}

The author declare that she has no competing interests.

Received: 24 September 2015 Accepted: 22 February 2016

Published online: 04 October 2016

\section{References}

Bair, J., and Werner, M. 2011. Commodity chains and the uneven geographies of global capitalism: a disarticulations perspective. Environment and Planning A, 43(5): 988-997.

Baldwin, R., and J. Lopez-Gonzalez. 2015. Supply-chain trade: a portrait of global patterns and several testable hypotheses. World Econ 38(11): 1682-1721.

Cattaneo, O., G. Gereffi, and C. Staritz (eds.). 2010. Global value chains in a postciris world. Washington: World Bank.

Coe, N.M., and H.W.-C. Yeung. 2015. Global production network. Oxford: Oxford University Press.

Coe, N.M., P. Dicken, and M. Hess. 2008. Global production networks: realizing the potential. J Econ Geogr 8: 271-295.

Coe, N., M. Hess, H. Yeung, P. Dicken, and J. Henderson. 2004. "Globalizing" regional development: a global production networks perspective. Trans Inst Br Geogr 29(4): 468-484.

Gereffi, G. 2014. Global value chains in a post-washington consensus world. Rev Int Polit Econ 21(1): 9-37.

Gereffi, G., J. Humphrey, and T.J. Sturgeon. 2005. The governance of global value chains. Rev Int Polit Econ 12(1): 78-104.

$\mathrm{He}, \mathrm{C}$. and Wang, J. 2012. Regional and sectoral differences in the spatial restructuring of chinese manufacturing industries during the post-WTO period. Geojournal, 77: 361-381.

He, C., P. Zou, and Y. Zhu. 2011. Spatial organization of multinational corporations in China. Eurasian Geogr Econ 52(6): 809-834.

Helble, M. and Ngiag, B. 2014. From global factory to global mall: East Asia's changing trade composition. ADBI Working Paper 496.

Henderson, J., and K. Nadvi. 2011. Greater China, the challenges of global production networks and the dynamics of transformation. Global Netw 11(3): 285-297.

Hong, E., and L. Hong. 2006. Dynamics of internationalization and outward investment. China Quarterly 287: 610-634

Hong Kong trade development council (2013) the search for low-cost production bases in Southeast Asia. HKTDC research, 16 July 2013.

Horner, R. 2014. Strategic decoupling, recoupling and global production networks: India's pharmaceutical industry. J Econ Geogr 14(6): 1117-1140.

Kaplinsky, R., A. Terbeggen, and J. Tijaja. 2011. China as a final market: the Gabon timber and Thai cassava value chains. World Develop 39(7): 1177-1190.

MacKinnon, D. 2012. Beyond strategic coupling: reassessing the firm-region nexus in global production networks. J Econ Geogr 12(1): 227-245.

O'Neill, J. 2011. The growth map: economic opportunity in the BRICS and beyond. New York: Penguin.

Pula, G. and Peltonen, T. A. 2009. Has emerging Asia decoupled? An analysis of production and trade linkages using the Asian International input-output table. Working Paper Series No. 993, European Central Bank.

The Economist (2015) Global manufacturing: made in China? 14 March 2015.

Timmer, M. P., Erumban, A. A., Los, B., Stehrer, R. and de Vries, G. J. 2014. Slicing up global value chains. J Econ Perspect 28(2): 99-118.

Wei, Y.H.D. 2015. Network linkages and local embeddedness of foreign ventures in China. Reg Stud 49(2): 287-299.

Yang, C. 2014. Market rebalancing of global production networks in the post-washington consensus globalizing era: transformation of export-oriented development in China. Rev Int Polit Econ 21(1): 130-156.

Yang, C. 2013. From strategic coupling to recoupling and decoupling: restructuring global production networks and regional evolution in China. Eur Plan Stud 21(7): 1046-1063.

Yang, C. 2012. Restructuring export-oriented industrialization in the pearl river delta, china: institutional evolution and emerging tension. App/ Geogr 32: 143-157.

Yang, C. 2009. Strategic coupling of regional development in global production networks: redistribution of taiwanese personal computer investment from the pearl river delta to the yangtze river delta. Reg Stud 43(3): 385-407.

Yang, C. 2007. Divergent hybrid capitalisms in China: Hong Kong and Taiwanese Electronics Clusters in Dongguan. Econ Geogr 83(4): 395-420. 
Yeung, H.W.-C., and N. Coe. 2015. Towards a dynamic theory of global production networks. Econ Geogr. doi:10.1111/ ecge.12063.

Yeung, H.W.-C. 2009. Regional development and the competitive dynamics of global production networks: an east asian perspective. Reg Stud 43(3): 325-352.

Zhang, J. 2014. Global financial crisis and the "spatial fix" of China's World Factory: The great "Long March"Inland. In Global economic crisis and the politics of diversity, ed. Atasoy Yeas, 132-154. London: Palgrave MacMillan.

Zhu, S., and J. Pickles. 2014. Bring In, Go Up, Go West, Go Out: upgrading, regionalisation and delocalisation in China' apparel production network. J Contemp Asia 44(1): 36-63.

Submit your manuscript to a SpringerOpen ${ }^{\circ}$ journal and benefit from:

- Convenient online submission

- Rigorous peer review

- Immediate publication on acceptance

Open access: articles freely available online

- High visibility within the field

- Retaining the copyright to your article

Submit your next manuscript at $\boldsymbol{\nabla}$ springeropen.com 